УДК $616.33+620+616.33$

\author{
Олена Сфіменко \\ Юлія Савченко \\ ТетянаФалалєсва \\ Тетяна Берегова \\ Микола Співак
}

\title{
Порівняльна дія сучасних прокінетиків та нанокристалічного діоксиду церію на моторну функцію травного тракту у щурів різного віку
}

Встановлено, що нанокристалічний діоксид церію посилював у старих щурів моторну активність шлунка та товстої кишки на відміну від церукалу та сенаде. Нанокристалічний діоксид церію - ефективніший прокінетику, ніж сучасні. Отримані результати можуть бути підгрунтям для створення на основі нанокристалічногодіоксиду церію протизакрепних засобів нового покоління.

Ключові слова: нанокристалічний діоксид церію, церукал, сенаде, моторна функція.

Постановка наукової проблеми та її значення. Пошук засобів, що нормалізують моторно-евакуаторну функцію травного тракту, привертає увагу лікарів-дослідників протягом кількох століть, оскільки порушення моторики лежать в основі патогенезу багатьох захворювань, таких як гастроезофагальна рефлексна хвороба, виразка шлунка, синдром подразненого кишечника, рак тощо [1;, c. 928-934].

Вікові зміни організму відбуваються в результаті старіння клітин і тканин, що зумовлюють значні порушення в регуляції функцій органів і систем. Травна система також зазнає вікових змін [3, с. 33-38; 4, с. 173-177]. Зокрема, у пацієнтів в літньому віці однією з найбільш поширених скарг $є$ закрепи, які можуть бути як самостійним симптомом функціонального характеру, так і симптомокомплексом, який супроводжує різні захворювання. Питання патогенезу і корекції закрепу викликають значний науковий і практичний інтерес, що отримало відображення в багатьох сучасних публікаціях [5; 6].

У клінічній практиці на сьогодні використовується широкий спектр послаблювальних засобів, але більшість 3 них має побічну дію, а до деяких розвивається звикання. До того ж, лікування літніх людей ускладнюється в зв'язку з різними супутніми захворюваннями пацієнтів.Тому пошук новихпрокінетиків з тривалим і безпечним терміном вживання - актуальне питання сучасної медицини. Таким засобом може бути нанокристалічний діоксид церію (НДЦ). На сьогодні новим напрямом досліджень є вплив наноструктур на біологічні системи. Встановлена вже антиоксидантна дія НДЦ [7, с. 46-49]. Крім того, виявлена здатність НДЦ активувати invivoсистеми клітинної та гуморальної імунної відповіді [8]. У попередніх наших дослідженнях ми встановили, що НДЦ має прокінетичну дію на моторику шлунка та товстої кишки[9, с. 67-74]. Тепер, на нашу думку, важливо встановити переваги НДЦ перед іншими сучасними прокінетиками. Отже, мета статті - порівняти дію сенаде, церукалу та нанокристалічногодіоксиду церію на голодну моторику шлунка та товстої кишки у щурів різного віку.

Матеріали та методи досліджень. Дослідження на тваринах проведені 3 дотриманням міжнародних принципів Європейської конвенції про захист хребетних тварин, що використовують для дослідних та інших наукових цілей [10].

Експерименти здійснено на 80 щурах віком 3 (40 щурів) та 24 (40 щурів) місяці. Кожна вікова група була розділена ще на чотири групи (по 10 щурів). Контрольним групам щурів 3 та 24 місяців внутрішньошлунково (в/ш) вводили 3 мл дехлорованої води. Іншим двом групам відповідного віку вводили церукал в дозі 0,5 мг/кг внутрішньоочеревинно (в/о). Двом групам щурів віком 3 та 24 місяці вводили сенаде в дозі 0,19 мг/кг (в/ш). Двоміншим групам щурів 3 та 24 місяці вводили НДЦ в дозі 1 ммоль/мл (в/ш). Всі речовини вводили протягом 10 днів.

Через добу після останнього введення речовин у щурів реєстрували моторну активність шлунка та товстої кишки за допомогою балонографічного методу [11, с. 61-67]. Упродовж доби перед експериментом щурів не годували, але у них був вільний доступ до води. Тварин наркотизували уретаном

(C) Сфіменко О., Савченко Ю., Фалалєєва Т., Берегова Т., Співак М., 2015 
(Sigma, USA) (1,1 г/кг живої ваги, в/о). Виконували щурам трахеотомію, після чого в фундальний відділ шлунка та товсту кишку вводили катетери з латексним балончиком, який заповнювали водою $37^{\circ} \mathrm{C}$. Молодим тваринам вводили в шлунок 1 мл води, в товсту кишку - 0,5 мл. Старим щурам вводили 1,5 мл та 0,7 мл відповідно. Тиск, створений після введення рідини, був однаковий у всіх експериментах. У тварин усіх груп після 20 -хвилинного еквілібраційного періоду упродовж 60 хв реєстрували спонтанну моторну активність. Для характеристики моторноїфункціїтравного тракту ми використовували амплітуду, частоту скорочень, індекс моторної активності (IMA),фазний та тонічний індекси (см вод. ст. *хв.) за 1 хв [11, с. 61-67].

У роботі були використані такі речовини: НДЦ, церукал, сенаде. НДЦ синтезовано у відділі проблем інтерферону та імуномодуляторів IMB ім. Д. К. Заболотного НАН України згідно з методикою [12]. НДЦ вводили піддослідній групі тварин в дозі 1 ммоль/мл (в/ш). Церукал («AWD.pharma $\mathrm{GmbH} \& \mathrm{Co.KG»;} \mathrm{«LTD} \mathrm{"PLIVACroatia"»,} \mathrm{Німеччина/Хорватія)} \mathrm{-} \mathrm{центральний} \mathrm{антагоніст}$ допамінових та серотонінових рецепторів, вводили вдозі 0,5 мг/кг (в/o).Сенаде («CiplaLtd», Індія) стимулюючий послаблювальний засіб рослинного походження, вводили в дозі 0,19 мг/кг (в/ш).

Статистичнаобробкаданихздійснюваласяупакетіпрограм «Statistica8.0». У зв’язку з невеликим обсяг вибірки для перевірки розподілу на нормальність застосовували $\mathrm{W}$-тест Шапіро-Вілка. Ймовірність похибки першого роду $\alpha>0,05$. Оскільки група наших даних виявилися нормально розподілена, то порівняння вибірок проводилося за допомогою методу t-критерію Стьюдента для зв'язаних вибірок [13, с. 459]. Розраховували середнє значення (M), стандартне відхилення (SD), рівень значущості складав $\mathrm{p}<0,05$.

Виклад основного матеріалу й обгрунтування отриманих результатів дослідження. У результаті проведених досліджень було встановлено, що у щурів з віком зменшується ІМАшлунка (рис.1). У старих щурів IMА був меншим на $19,5 \%$ ( $<<0,05)$, ніж у молодих. Ми проаналізували дію трьох речовин на IMA шлунка у двох вікових груп. Було встановлено, що у старих щурів церукал зменшував ІМАна 24,8\% (p <0,05), сенаде на - 13,4 \% ( $<<0,05)$, тоді як НДЦ, навпаки посилював IMА шлунка у цих щурів.

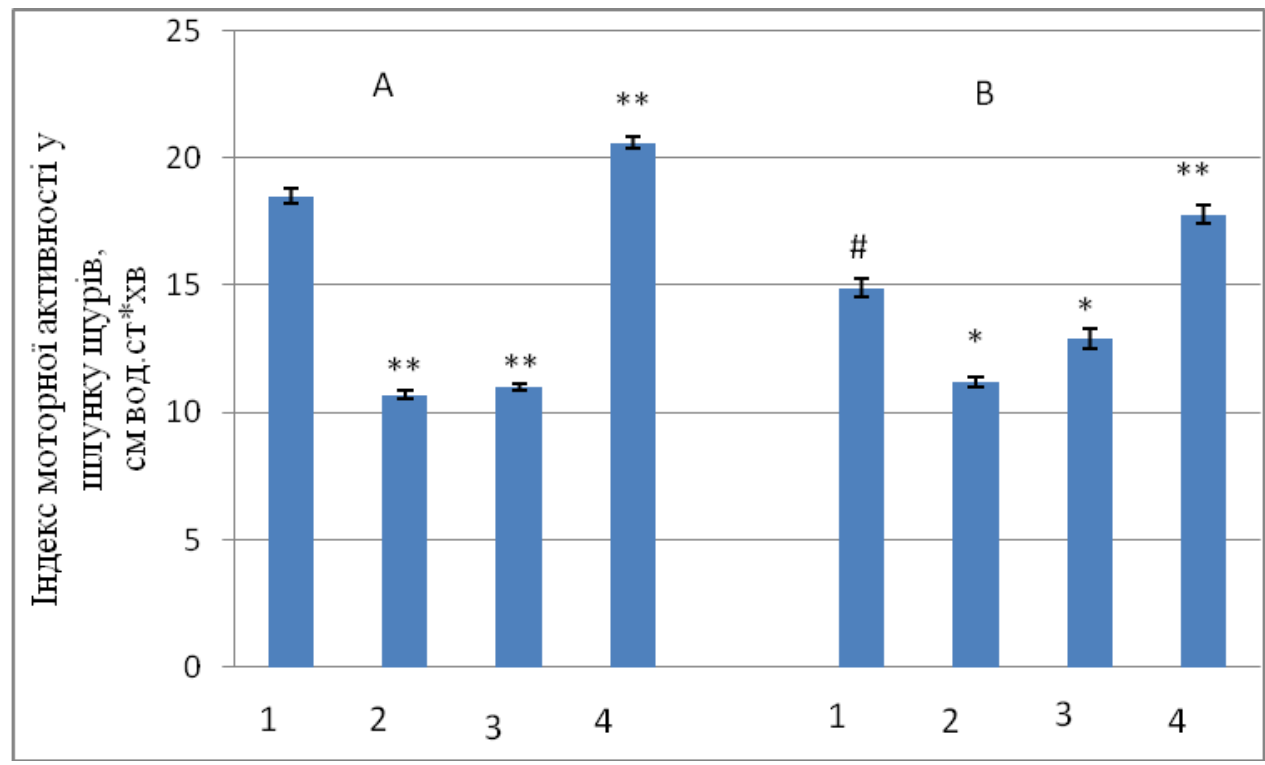

Рис. 1. Індекс моторної активності шлунку у щурів 3 (А) та 24 (В) місяців: 1 - контроль; 2 - церукал; 3 сенаде; 4 - нанокристалічнийдіоксид церію. Примітка: * $\mathbf{p}<0,05, * * \mathbf{p}<0,01$, порівняно 3 відповідним контролем, \# р < 0,01 відносно 3-місячного контролю

Оскільки IMА - це величина, в розрахунок якої входять амплітуда, частота, фазний та тонічний індекси, то важливо встановити, за рахунок яких величин цей показник змінюється. Аналіз отриманих результатів показав, що з віком у шлунку щурів частота скорочень зменшується на 37,5 \% (p <0,05) (рис. 2). Церукал значно знижував частоту скорочень шлунка у молодих та старих щурів. Так, у молодих частота скорочень зменшувалася на 94,6 \% (p <0,01), у старих - на 94,3 \% (p <0,01). 
Сенаде, на противагу церукалу, посилював частоту скорочень шлунка у щурів обох вікових груп. У молодих щурів частота скорочень зростала на 105,4 \% (p <0,01), а у старих - на $502 \%$ (p <0,001). У старих щурів сенаде діяв сильніше на частоту скорочень шлунка, ніж у молодих. НДЦ не впливав на частоту скорочень шлунку щурів обох вікових груп.

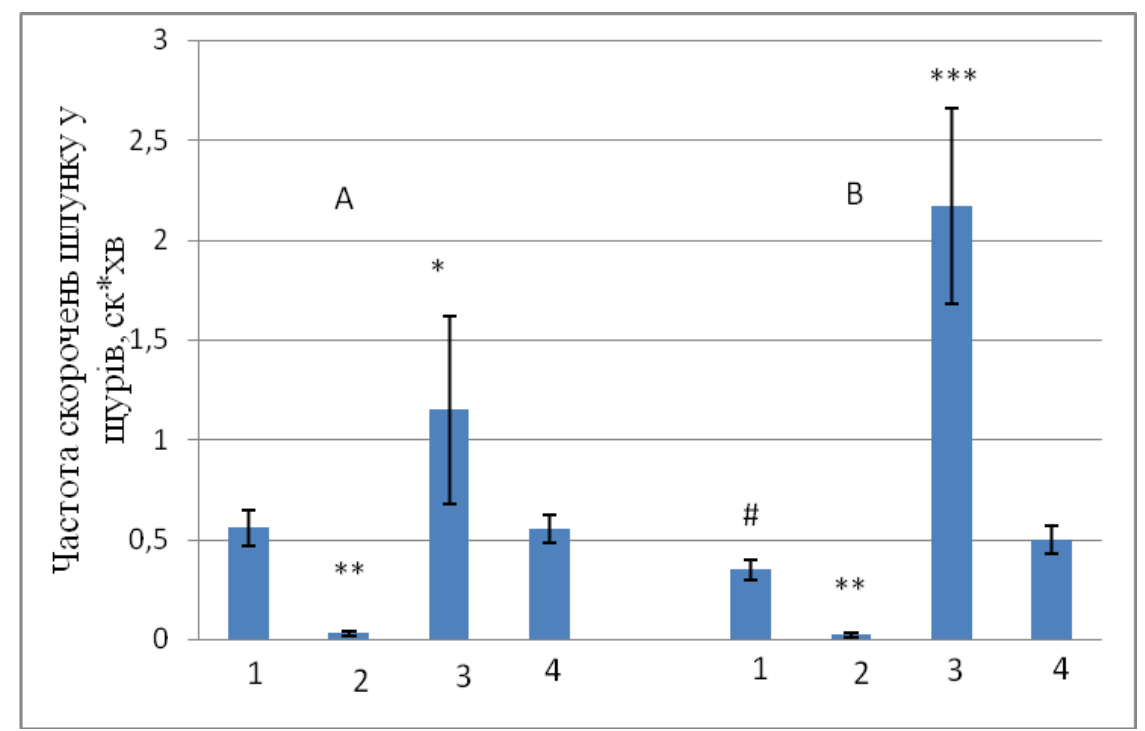

Рис. 2. Частота скорочень шлунку у щурів 3 (А) та 24 (В) місяців: 1 - контроль; 2 - церукал; 3 - сенаде; 4 - нанокристалічний діоксид церію. Примітка: ** p $<0,01, * * *$ p $<0,001$ порівняно 3 відповідним контролем, \# р <0,01 відносно 3-місячного контролю

Ми також встановили, що у старих щурів зменшується амплітуда скорочень шлунка на 66 \% (р $<0,05$ ), порівняно 3 молодими (рис. 3). У старих та молодих щурів церукал статистично значуще знижував амплітуду скорочень на $80 \%$ ( $<<0,01)$ та $90 \%$ ( p <0,001) відповідно. Сенаде знижував амплітуду скорочень лише у молодих щурів на $66,7 \%$ (p <0,01). НДЦ на амплітуду спонтанних скорочень у шлунку щурів статистично значуще не впливав. Отже, прокінетична дія сенаде в шлунку зумовлена посиленням частоти та амплітуди спонтанних скорочень.

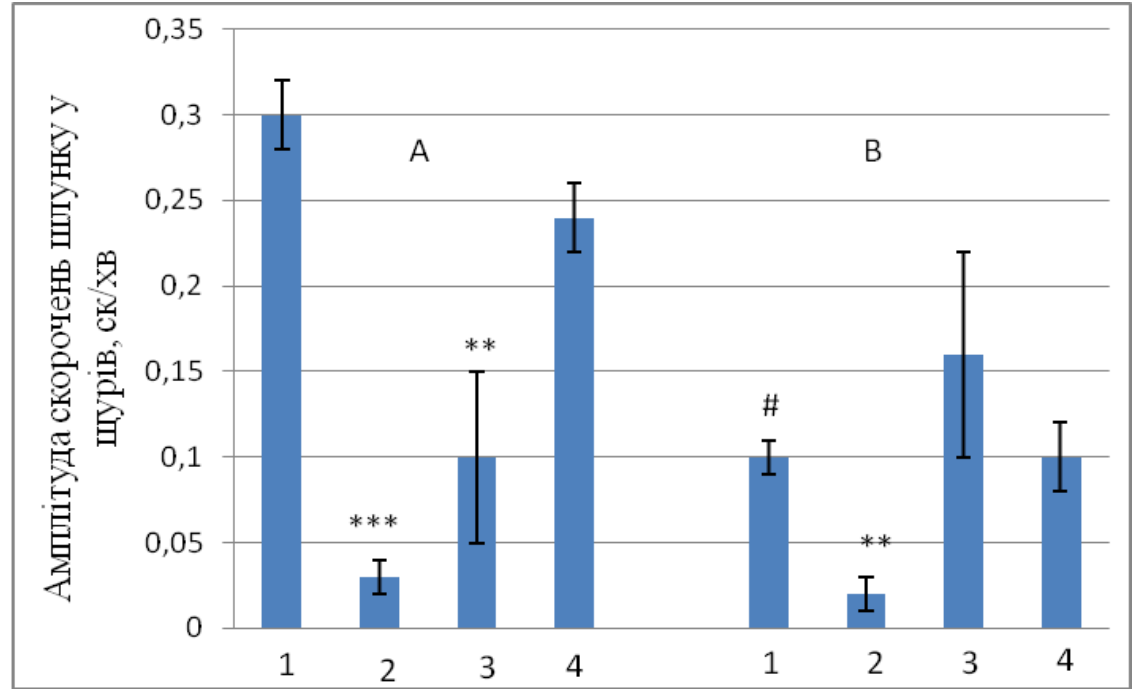

Рис. 3. Амплітуда скорочень шлунку у щурів 3 (А) та 24 (В) місяців: 1 - контроль; 2 - церукал; 3 - сенаде; 4 - нанокристалічнийдіоксид церію. Примітка: * $\mathbf{p}<0,05$, ** $\mathbf{p}<0,01$ порівняно 3 відповідним контролем, \# р <0,05 відносно 3-місячного контролю

Фазний індекс визначає роботу м'язового апарату стінки травного тракту. Ми встановили, що фазний індекс спонтанних скорочень шлунка зменшується у старих щурів на $20 \%(p<0,05)$ 
порівняно з молодими (рис. 4). Церукал знижував цей показник в обох вікових груп. У молодих щурів фазний індекс знижувався на $60 \%$ (p <0,01), а у старих - на $55 \%$ (p <0,01). На противагу церукалу, сенаде збільшував фазний індекс у молодих щурів на $40 \%$ (p <0,001), у старих - на $375 \%$ ( $\mathrm{p}<0,001)$. У старих щурів дія сенаде виявилась ефективнішою, ніж у молодих. Аналогічно НДЦ посилював фазний індекс у щурів обох вікових груп. Так, у молодих щурів він зростав на $140 \%$ (p $<0,001)$, а у старих щурів - на $250 \%$ ( $<<0,001)$. Дія НДЦ у старих щурів виявилася сильнішою, ніж у молодих. Можливо, це пояснюється тим, що з віком виникають значні порушення моторного апарату травного тракту, тому ефективність препарату краща у вікової групи тварин.

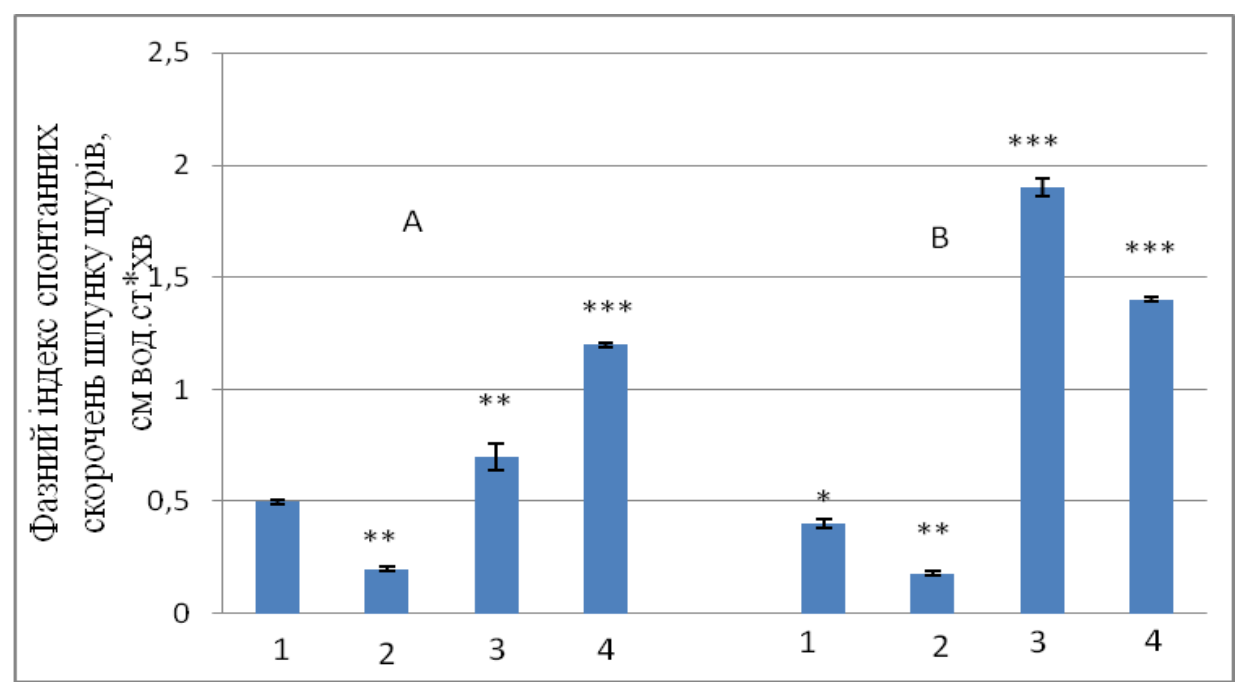

Рис. 4. Фазний індекс спонтанних скорочень шлунка у щурів 3 (А) та 24 (В) місяців: 1 -контроль;

2 - церукал; 3 - сенаде; 4 - нанокристалічний діоксид церію. Примітка: * p <0,05, ** p <0,01, *** p <0,001 порівняно з відповідним контролем

Зміни тонічного індексу виявилися статистично незначимими при порівнянні старих та молодих щурів (рис. 5). Але церукал знижував тонічний індекс у молодих щурів на $50 \%$ (p <0,05), у старих щурів - на 77,8 \% (p < 0,001). Сенаде не впливала на тонічну активність товстої кишки як у молодих, так і у старих щурів. НДЦ також зменшував тонічний індекс товстої кишки щурів обох вікових груп: у молодих - на 45,8 \% (p < 0,05), у старих - на 42,6 \% (p <0,05).

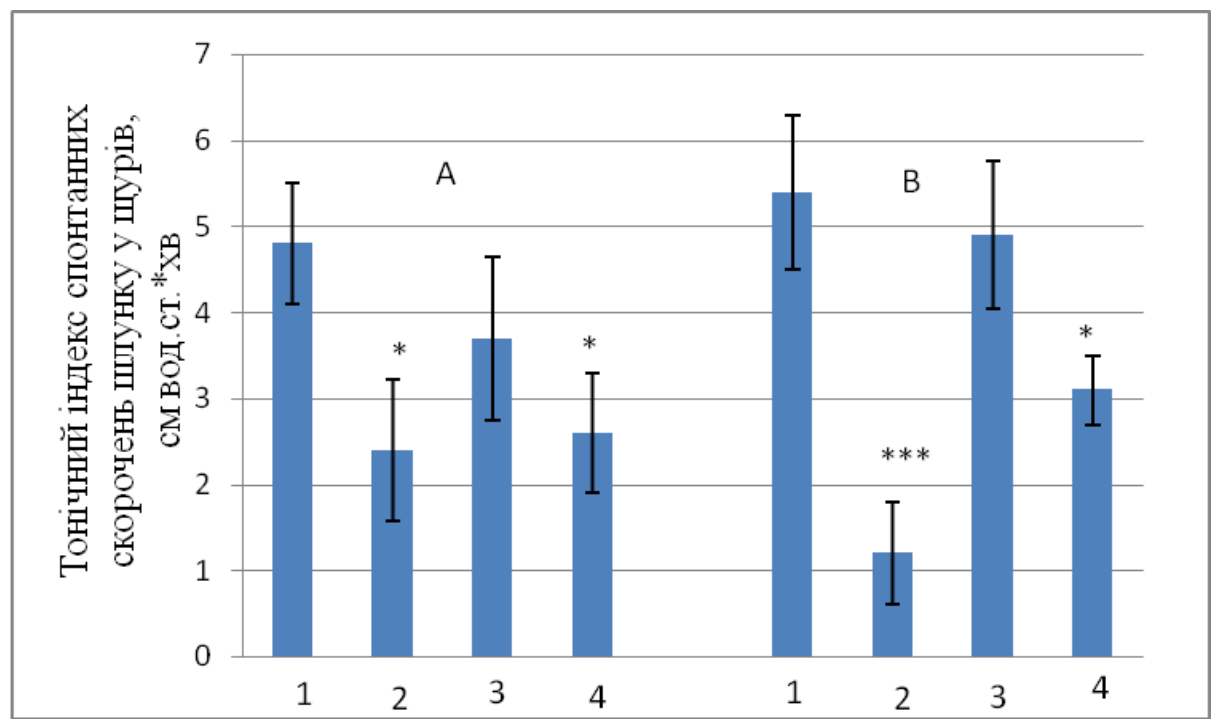

Рис. 5. Тонічний індекс спонтанних скорочень шлунка у щурів 3 (А) та 24 (В) місяців: 1 - контроль; 2 - церукал; 3 - сенаде; 4 - нанокристалічний діоксид церію. Примітка: * $\mathbf{p}<0,05$, *** p $<0,001$ порівняно з відповідним контролем 
Таким чином, ми спостерігали, що з віком знижується спонтанна моторна активність шлунка за усіма показниками, крім тонічного. Наші результати узгоджуються з даними літератури [14, с. 490-501]. При цьому дія прокінетиків виявилася різною. Церукал знижував всі показники моторної активності. Стимулююча дія сенаде в шлунку зумовлена посиленням частоти, амплітуди та фазного індексу спонтанних скорочень, при цьому IMА знижувався. Порівняно з цими відомими препаратами НДЦ посилював всі показники моторної активності, крім тонічного індексу. Можливо, це спричинено тим, що з віком тонічний індекс теж не змінювався.

Аналіз моторної активності товстої кишки показав, що ІМАзнижується у щурів з віком на 14,7 \% (p < 0,05) (рис. 6). Встановлено, що у молодих щурів церукал та сенаде зменшували IMA на 22,1\% ( $<<0,01)$ та $25,72 \%(\mathrm{p}<0,01)$ відповідно. Аналогічну дію ми спостерігали і у старих щурів: церукал зменшував IMA на $12,1 \%$ ( $<<0,05)$, а сенаде - на7,8 \% ( $<<0,05)$. На противагу цим речовинам, НДЦ посилював IMA в обох вікових груп. У молодих щурів IMA зростав на $13,2 \%$ (p < 0,05), тоді як у старих - на $14,7 \%(\mathrm{p}<0,05)$.

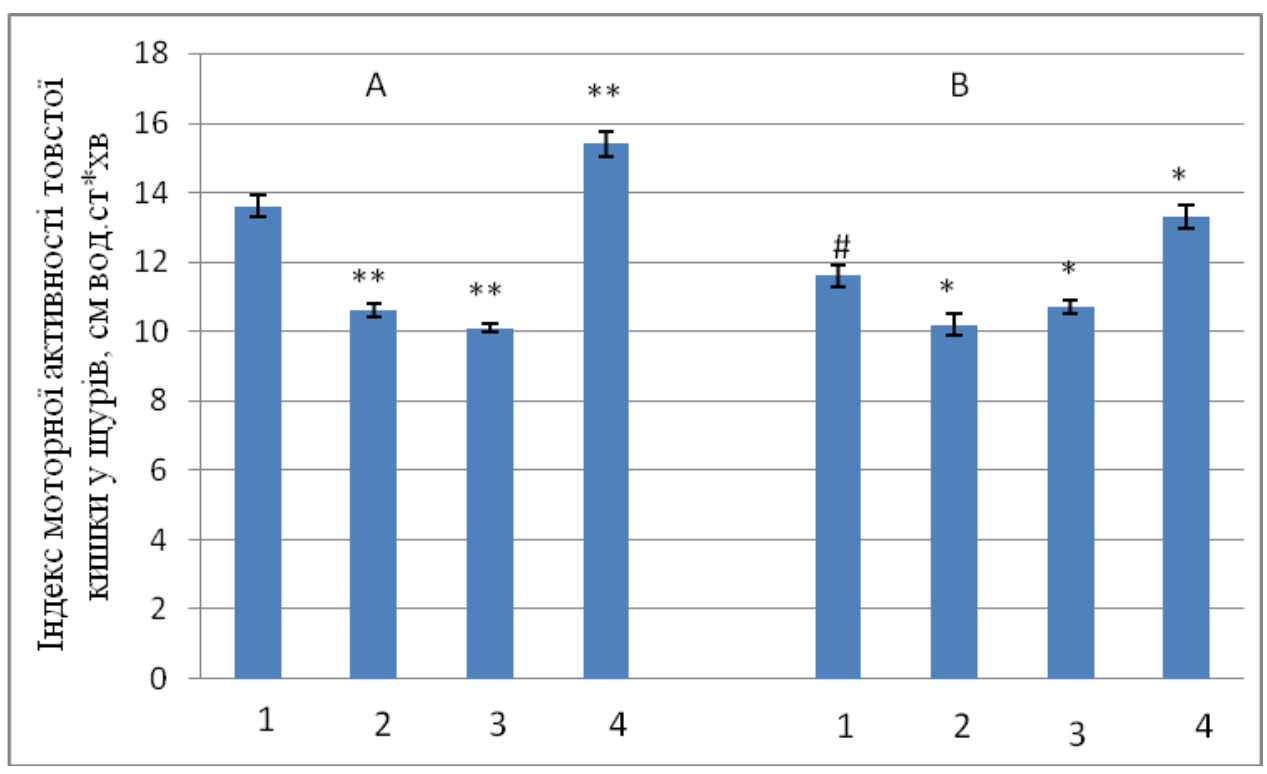

Рис. 6. Індекс моторної активності спонтанних скорочень товстої кишки у щурів 3 (А) та 24 (В) місяців: 1 - контроль; 2 - церукал; 3 - сенаде; 4 - нанокристалічнийдіоксид церію.

Примітка: * p < 0,05, ** p < 0,01, порівняно з відповідним контролем, \# $\mathrm{p}<0,01$ відносно 3-місячного контролю

Подальший аналіз моторної активності травного тракту виявив, що у старих щурів зменшується частота скорочень товстої кишки на 32,3 \% ( $<0,05)$ порівняно з молодими (рис. 7). Дія церукалу, сенаде та НДЦ виявилася різною. Так церукал зменшував частоту скорочень як у молодих, так і у старих щурів на 48,4 \% (p < 0,01) та 33,3\% (p < 0,05) відповідно. Сенаде, навпаки, посилював частоту скорочень товстої кишки обох груп щурів. У молодих та старих щурів частота скорочень зростала на $48,4 \%(\mathrm{p}<0,01)$ та $457 \%(\mathrm{p}<0,05)$ відповідно. Вплив сенаде у старих щурів виявився ефективнішим, ніж у молодих. НДЦ у молодих щурів не впливав на частоту скорочень товстої кишки, тоді як у старих викликав посилення скорочень на 33,3 \% (р < 0,05).

Отримані результати вказують на те, що у старих щурів значно знижується амплітуда спонтанних скорочень товстої кишки на $65 \%$ ( $<0,05)$ порівняно $з$ молодими (рис. 8). Церукал знижував амплітуду спонтанних скорочень як у молодих, так і старих щурів. У молодих тварин зниження було на $66,7 \%(\mathrm{p}<0,01)$, а у старих - на 90,5\% (p<0,01). Аналогічно сенаде зменшував амплітуду скорочень у молодих щурів на $83,3 \%(\mathrm{p}<0,01)$, у старих - на $52,4 \%(\mathrm{p}<0,01)$. Напротивагу цим препаратам НДЦ посилював амплітуду спонтанних скорочень у старих щурів на 42,9 \% (p <0,05). У молодих тварин НДЦ не впливав на амплітуду спонтанних скорочень. 


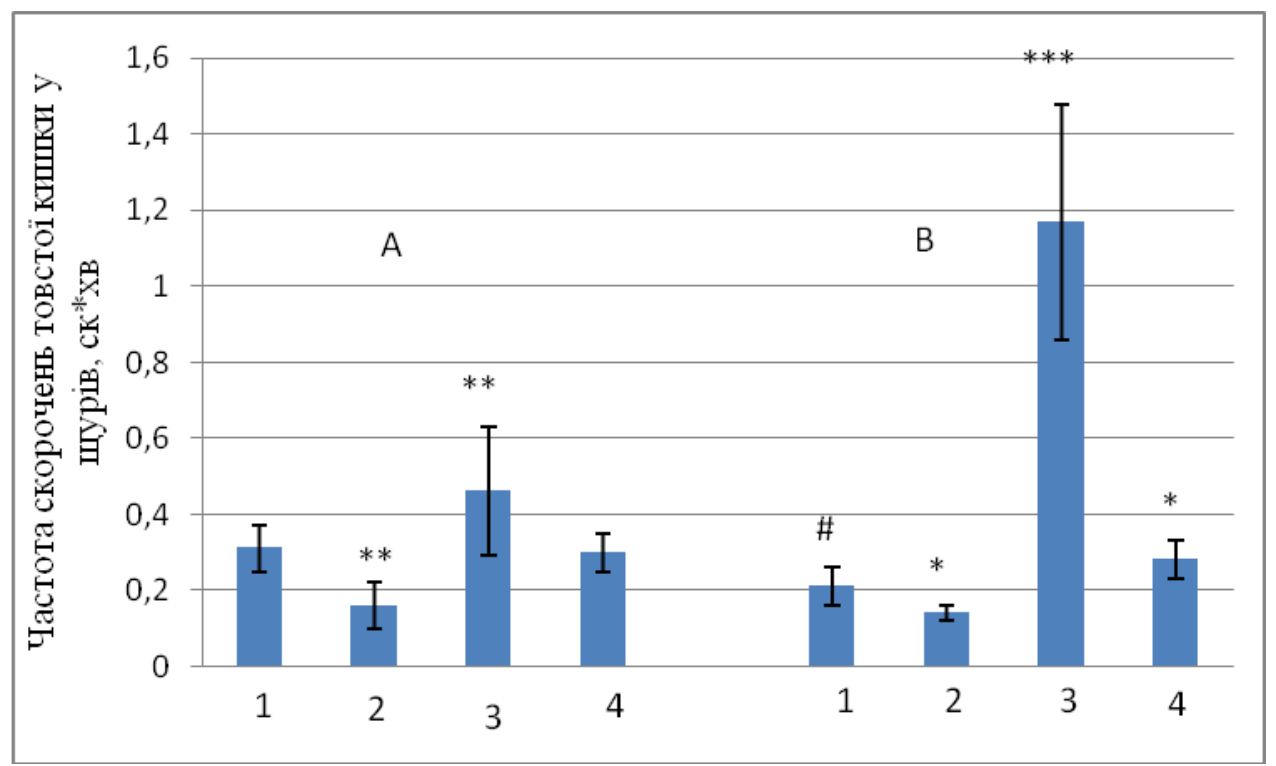

Рис. 7. Частота спонтанних скорочень товстої кишки у щурів 3 (А) та 24 (В) місяців: 1 -контроль; 2 - церукал; 3 - сенаде; 4 - нанокристалічнийдіоксид церію. Примітка: * p <0,05, ** p <0,01, *** p <0,001порівняно 3 відповідним контролем, \# p<0,01 відносно 3-місячного контролю.

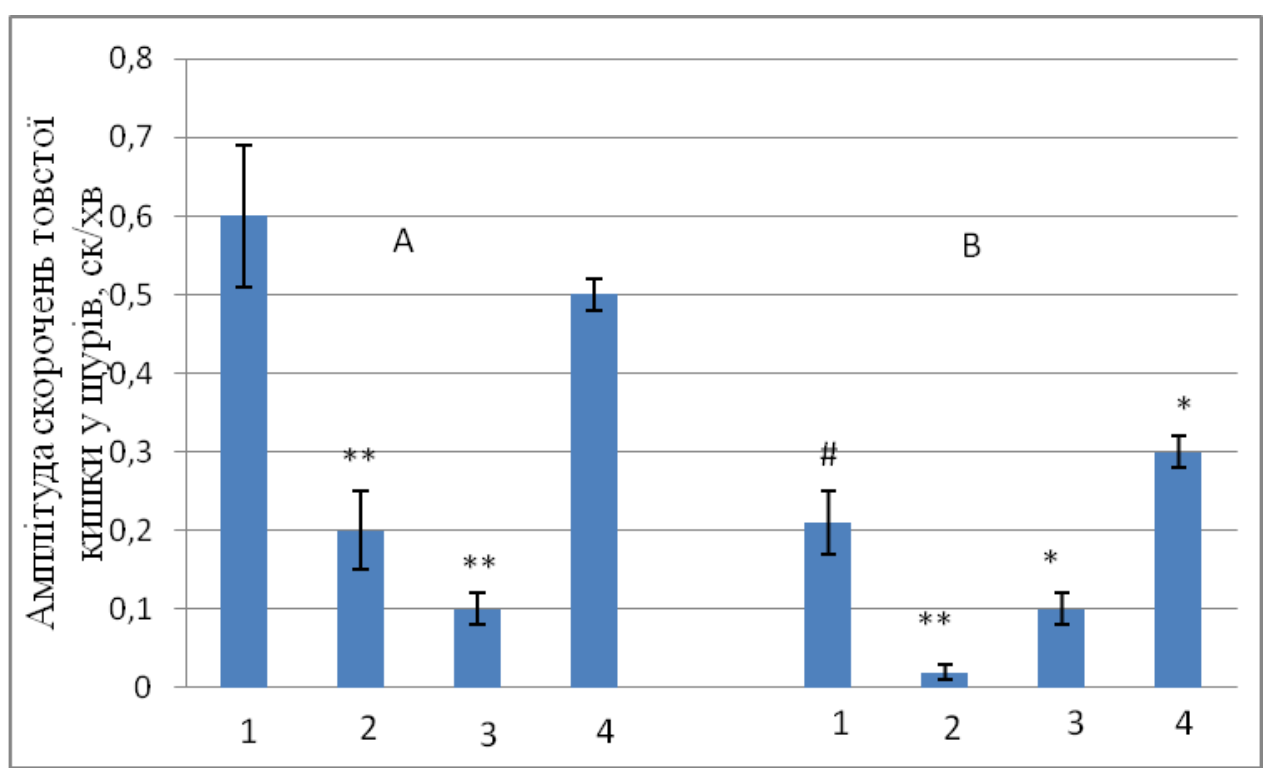

Рис. 8. Амплітуда спонтанних скорочень товстої кишки у щурів 3 (А) та 24 (В) місяців: 1 -контроль; 2 - церукал; 3 - сенаде; 4 - нанокристалічнийдіоксид церію. Примітка: * p <0,05, ** р <0,01 порівняно 3 відповідним контролем, \# р<0,05 відносно 3-місячного контролю

Вплив досліджуваних речовин на фазний індекс теж виявився різнонаправленим. У молодих щурів церукал збільшував фазний індекс на $27,3 \%$ ( $<0,05)$, тоді як у старих статистично значущого впливу не спостерігалося (рис. 9). Сенаде, навпаки, у молодих щурів знижувала фазний індекс на $45,5 \%$ (р <0,05), тоді як у старих також не здійснював впливу. НДЦ значно посилював фазний індекс у молодих і старих щурів. У молодих щурів фазний індекс зростав на $136,4 \%$ (p<0,001), а у старих на $139,1 \%(\mathrm{p}<0,001)$. 


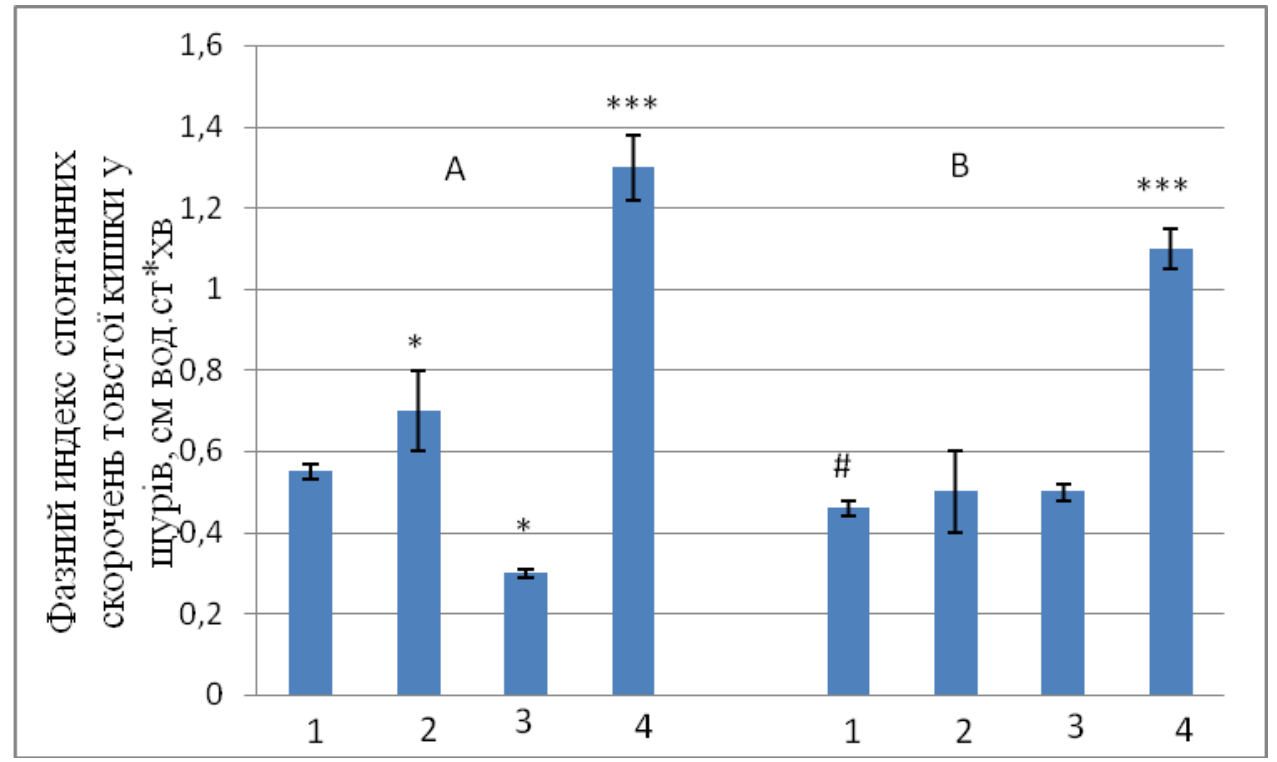

Рис. 9.Фазний індекс спонтанних скорочень товстої кишки у щурів 3 (А) та 24 (В) місяців: 1 контроль; 2 - церукал; 3 - сенаде; 4 - нанокристалічнийдіоксид церію.

Примітка: * $\mathrm{p}<0,05, * * * \mathrm{p}<0,001$ порівняно з відповідним контролем, \# $<<0,05$ відносно 3-місячного контролю

Щодо тонічного індексу, то з віком він не змінювався. Сенаде та НДЦ не впливали на цей показник, тоді як церукал посилював тонічний індекс в обох вікових груп (рис.10). У молодих щурів це збільшення відповідало $63 \%(\mathrm{p}<0,05)$, а у старих $-76 \%(\mathrm{p}<0,05)$.

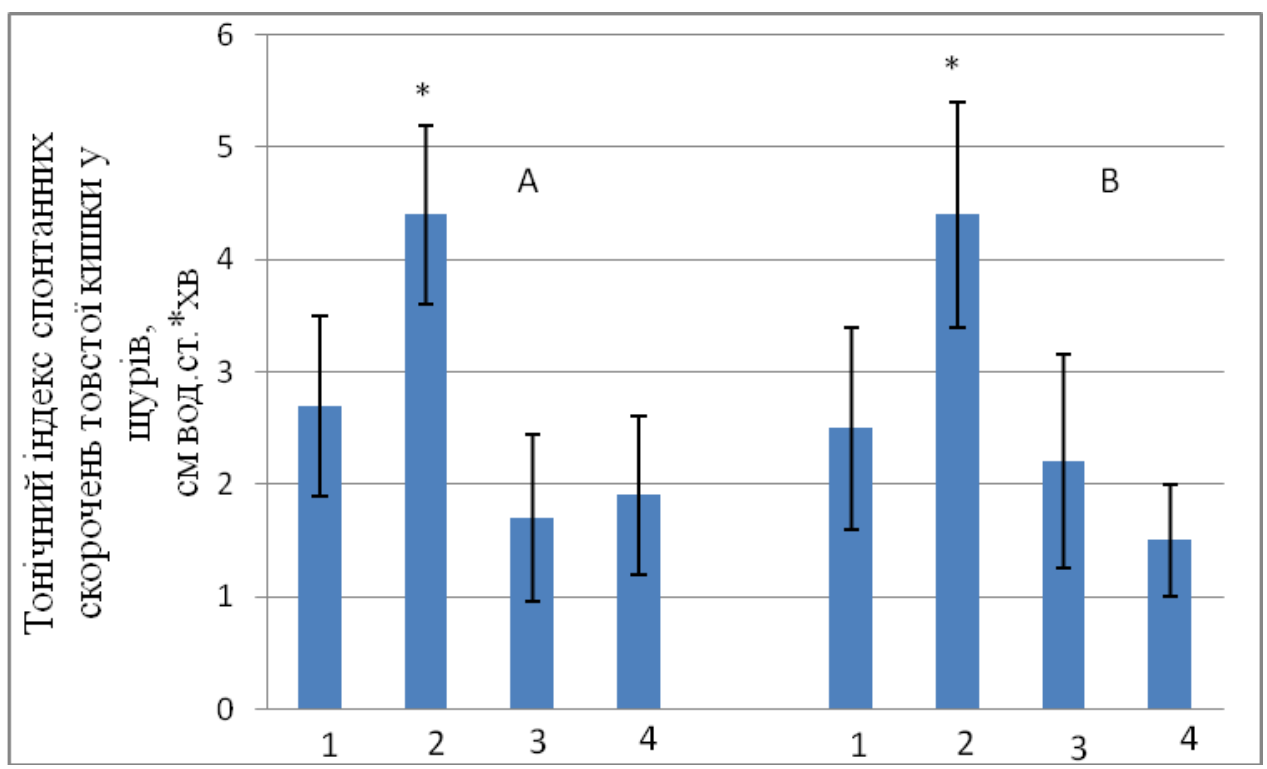

Рис. 10. Тонічний індекс спонтанних скорочень товстої кишки у щурів 3 (А) та 24 (В) місяців: 1 - контроль; 2 - церукал; 3 - сенаде; 4 - нанокристалічнийдіоксид церію. Примітка: * p <0,05

Отримані результати $\epsilon$ надзвичайно цікавими. Адже зниження моторної активності за всіма показниками у старої групи градусів може бути передумовою виникнення закрепів[15, с. 173-177.]. Як відомо, 42 \% людей похилого віку страждають на виникнення закрепів, крім того, цей відсоток зростає після 65 років [16, с. 1226-1231].За отриманими результатами найкращий прокінетичний ефект мав НДЦ. Він мав стимулюючу дію на всі показники моторної активності. При цьому церукал стимулював лише фазний індекс у молодих щурів та тонічний індекс, тоді як всі інші показники значно пригнічував. Сенаде стимулював лише частоту скорочень товстої кишки. Таким чином, для людей 
похилого віку з схильністю до виникнення закрепів найкращу прокінетичну дію матиме НДЦ. Зважаючи ще й на його антиоксидантну дію, він може бути геропротектором, що також важливо для осіб похилого віку.

Висновки та перспективи подальшого дослідження. Отже, церукал знижував всі показники моторної активності шлунка та стимулював лише фазний індекс та тонічний індекс товстої кишки. Стимулююча дія сенаде в шлунку зумовлена посиленням частоти, амплітуди та фазного індексу спонтанних скорочень, при цьому IMА знижувався. Сенаде стимулював частоту скорочень товстої кишки. НДЦ посилював всі показники моторної активності шлунка та товстої кишки.

Таким чином, на основі нанокристалічного діоксиду церію можуть бути створені протизакрепні засоби нового покоління.

\section{Джерела та література}

1. Gut motility and enteroendocrine secretion / T. Wu, C.K.Rayner, R.L. Young, M. Horowitz // Curr Opin Pharmacol. - 2013. - Vol. 13. - N 6. - P. 928-934.

2. Gastroesophageal and extraesophageal reflux symptoms: Similarities and differences / M. Drinnan, J. Powell, A. Nikkar-Esfahani, R. C. Heading, J.Doyle // Laryngoscope. - 2014. - N. 30.

3. Rayner C. K. Physiology of the ageing gut / C. K. Rayner, M. Horowitz // Curr Opin Clin Nutr Metab Care. 2013. - Vol. 16, N.1. - P. 33-38.

4. Britton E. Ageing and the gut / E. Britton, JT. McLaughlin // ProcNutr Soc. - 2013. - Vol. 72(1) - - P. 173-177.

5. Werth B. L. A longitudinal study of constipation and laxative use in a community-dwelling elderly population / B. L. Werth, K. A.Williams, L. G. Pont //Arch Gerontol Geriatr. - 2015. - Vol. 16.

6. Effect of Different Surgical Options on Curative Effect, Nutrition, and Health Status of Patients with Slow Transit Constipation / F. Li, T. Fu, W. Tong, A. Zhang, C. Li, Y Gao// Int J Colorectal Dis. - 2014. Vol. 29 (12). - P. 1551-1556.

7. Prasad RGSV. Cerium oxide nanoparticles protects gastrointestinal mucosa fromethanol induced gastric ulcerinin-vivo animal model / RGSV Prasad, R. Davan, S. Jothi, A. R. Phana, D. B. Raju // Nano Biomed Eng. - 2013. - Vol. 5 (1). - P. 46-49.

8. Жолобак Н. М. Ефективність застосування наночастинок колоїдного церію та L.bulgaricus у мишей / Н. М. Жолобак, Т. К. Журавська, І. І. Качмарська та ін. // Довкілля та здоров'я : матеріали конф. Тернопіль, 2009. - С. 32.

9. Зміни моторної функції шлунка та товстої кишки у щурів за умов дії нанокристалічного діоксиду церію / О. Ю. Єфіменко, Ю. О. Савченко, Т. М. Фалалєєва та ін. // Фізіологічнийжурнал. - 2014. T. 60, № 3. - С. 67-74.

10. Мурзін О. Б. Свропейська конвенція про захист хребетних тварин, що використовуються для дослідних та інших наукових цілей / О. Б. Мурзін. - Дніпропетровськ : Вид-во Дніпропетр. ун-ту, 2004.

11. Imidazoline versus alpha-adrenoceptors in the control of gastric motility in mice / Z. S. Zádori, Á.Fehér, M. Al-Khrasani et al. // Eur J Pharmacol. - 2013. - 705(1-3): 61-67.

12. Одностадийный синтез коллоидных растворов диоксида церия для биомедицинского применения / О. С. Иванова, Т. О. Шекунова, В. К. Иванов и др. // Докл. Акад. наук. - 2011. - Т. 437, № 5. - С. 638-641.

13. Гланц С. Медико-биологическаястатистика / С. Гланц. - М. : Практика, 1998. - С. 459.

14. Agingandgastrointestinal neuromuscular function: insights from within and outside the gut / K. Bitar, B. Greenwood-Van Meerveld, R. Saad, J. W. Wiley // NeurogastroenterolMotil. - 2011. - Vol. 23(6). - P. 490-501.

15. Britton E. Ageing and the gut / E. Britton, J. T. McLaughlin //ProcNutr Soc. - 2013. - Vol. 72(1). - P. 173-177.

16. Orr W. C. Aging and neural control of the GI tract: IV. Clinical and physiological aspects of gastrointestinal motility and aging / W. C Orr, C. L. Chen // Am J Physiol Gastrointest Liver Physiol. - 2002. - Dec-Vol. 283(6). P. 1226-1231.

Ефименко Елена, Савченко Юлия, Фалалеева Татьяна, Береговая Татьяна, Спивак Николай. Сравнительное действие современных прокинетиков и нанокристаллического диоксида церия на моторную функцию пищеварительного тракта у крыс разного возраста. В данной работе проводилось сравнительное исследование действия церукала, сенаде и НДЦ на моторную функцию желудка и толстой кишки у крыс. Эксперименты проводились баллонографическим методом. Показано, что церукал уменьшал моторный, тонический и фазный индексы, амплитуду, частоту сокращений желудка и толстой кишки у крыс. Сенаде увеличевал только частоту сокращений, тогда как другие показатели моторной активности уменьшал. Установлено, что НДЦ стимулировал амплитуду, частоту, моторный и фазный индексы спонтанной сократительной активности желудка и толстой кишки у крыс обеих возрастных групп. Таким образом, НДЦ проявляет более эффективное прокинетическое действие, чем современные прокинетики. На основе НДЦ могут быть созданы прокинетики нового поколения.

Ключевые слова: нанокристаллический диоксид церия, церукал, сенаде, моторная функция. 
Iefimenko Olena, Savchenko Iuliia, Falalyeyeva Tetyana, Beregova Tetyana, Spivak Mykola. The Comparative Action of the Modern Prokinetics and Nanocrystalline Cerium Dioxide on the Motor Function of the Digestive Tract in the Rats of Different Ages. In this paper was carried out a comparative study of action of the cerucal, sennosides and NCD on motor function of the stomach and colon in rats. The experiments were performed by ballonographic method.It is shown that cerucal reduces motor, tonic and phasic indexes, amplitude, frequency of the contractions of the stomach and colon in rats. Sennoides increased only the frequency of the contractions, whereas other parameters of motor activity it decreases. It was found that the NCD has stimulated the amplitude, frequency, phase and motor indexes of spontaneous contractile activity of the stomach and colon in rats of both age groups. Thus, the NDC showed effective prokineticffects than current prokinetics. Based on the NCD can be created a prokineticsa new generation.

Keywords:nanocrystalline cerium dioxide, cerucal, sennosides, motor function.

Стаття надійшла до редколегії $02.02 .2015 \mathrm{p}$.

УДК 612.821:575.16

\section{Тетяна Качинська \\ Ольга Абрамчук \\ Ілля Кузнєцов}

\section{Особливості джерел викликаної активності кори головного мозку в лівшів та правшів під час класифікації стимулів, пов'язаних із локалізацісю та формою об'єкта}

Мета роботи полягала у вивченні особливостей джерел викликаної активності кори головного мозку та їх локалізації в лівшів та правшів під час класифікації стимулів, пов'язаних із локалізацією та формою об’єкта. У дослідженні брали участь 33 особи чоловічої статі, віком 18-20 років, які були поділені на дві групи - лівші (14 осіб) та правші (19 осіб). У досліджуваних осіб із лівим типом сенсомоторної асиметрії, незалежно від експериментальної ситуації, найбільш типові джерела електричної активності зафіксовані здебільшого в задньоасоціатівних ділянках лівої півкулі. У правшів розміщення диполів у двох експериментальних ситуаціях менш одноманітне. Так, під час першого тесту найбільш стаціонарні диполі зафіксовані в лівій півкулі, другого - у правій.

Ключові слова: викликані потенціали, правші, лівші, джерело електричної активності, диполь.

Постановка наукової проблеми та ї̈ значення. Зорова система людини здатна ефективно фіксувати патерни інтенсивності світла, які відбиваються від різних об'єктів (предметів, істот та ін.) та отримувати з них біологічно значиму інформацію. У результаті подальшої обробки цієї інформації відбувається формування внутрішнього представлення об’єктів зовнішнього світу в мозку, на підставі якого здійснюється адекватна поведінка. В основі первинних етапів обробки інформації лежить принцип детекції значущих ознак зобра-ження, які згодом кодуються активністю поодиноких нейронів - детекторів зорової кори і їх функціональними ансамблями [ 6, с. 3].

У зоровому аналізаторі виділяють дві системи обробки інформації: «Що?» і «Де?». Система «Що?» впізнає об'єкт. Сигнали в системі «Що?» беруть початок від гангліозних клітин сітківки типу Х та досягають нижньотім'яної кори, де відбувається інтеграція ознак об'єкта. Окремі ознаки об'єкта обробляються паралельно в різних зонах. У VI локалізовані детектори, чутливі до різної орієнтації ліній і їх довжині. У V3 нейрони реагують на форму предмета і його більш складні елементи, ніж у VI. У зоні V4 локалізовані константні детектори кольору. Нейрони кори V5 вибірково відповідають на різні напрямки і швидкості руху об'єкта [2, с. 41].

Система «Де?» визначає локалізацію об’єкта в зовнішньому зоровому полі. Вона бере свій початок від гангліозних клітин сітківки типу Y та досягає парієтальної кори. У нейронах парієтальної кори рецептивні поля представлені ділянками зорового поля [2, с. 41].

(C) Качинська Т., Абрамчук О., Кузнєцов I., 2015 